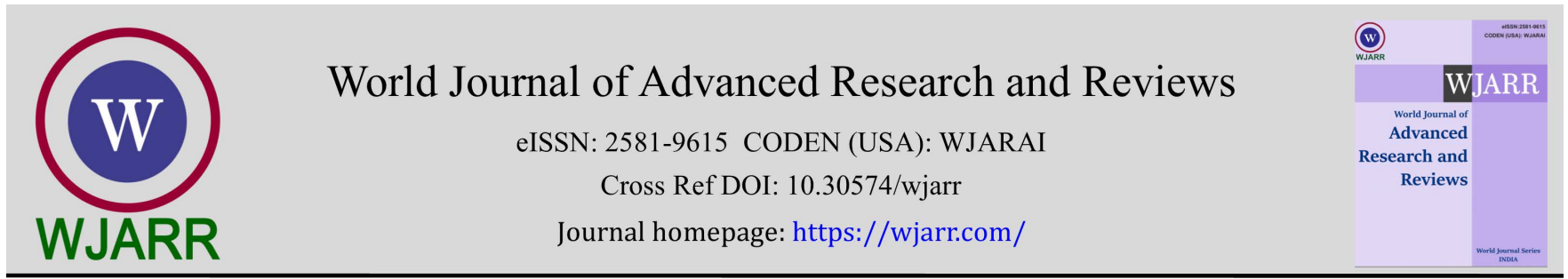

(RESEARCH ARTiClE)

Check for updates

\title{
Increasing knowledge of the Inpres elementary school students in Rimuku, Mamuju- Sulawesi Barat regarding Covid-19 and its prevention
}

\author{
Marsa Safira 1, Aisha Maharani Aliski 1, Bella Salsabila 1, Dewi Ratna Sari 2, *, Muhammad Anas Farobi 1 \\ Nadyalifa Tania Putri 1, Dhia Farhan Taufik 1, Hammam Izza Rofiqi 1, Daniel Jonatahan Mangapul Siagian ${ }^{1}$ \\ and Anisa Putri Amanda 1
${ }^{1}$ Medical Program, Faculty of Medicine, Universitas Airlangga, Surabaya, East Java, Indonesia
${ }^{2}$ Department of Anatomy, Histology and Pharmacology, Faculty of Medicine, Universitas Airlangga, Surabaya, East Java, Indonesia.

World Journal of Advanced Research and Reviews, 2022, 13(01), 693-699

Publication history: Received on 10 December 2021; revised on 12 January 2022; accepted on 14 January 2022

Article DOI: https://doi.org/10.30574/wjarr.2022.13.1.0053

\begin{abstract}
Coronavirus-disease-2019 (COVID-19) was declared a pandemic by WHO on March 11, 2020. This disease can affect both adults and children. COVID-19 in children rarely causes symptoms (asymptomatic) or only causes mild symptoms. For these reasons, children are a high-risk group of transmission sources for families. This study aimed to analyze the knowledge level before and after socialization about COVID-19 and its prevention of students in Inpres Rimuku Elementary School, Mamuju Regency, and West Sulawesi. This study used the descriptive-analytic design using a questionnaire containing seven questions via a google form filled in two sessions, namely before and after educational socialization. Students were given online socialization about COVID-19 and its prevention. The data were analyzed descriptively by calculating the mean, percentage, and inferential statistics by Wilcoxon Signed rank test and Spearman's correlation. As a result, thirty-six students have been involved in the socialization. Most students were ten years old (50\%) and from 5th grade (69\%). There was a significant increase in the students' knowledge on COVID-19 and its prevention of $18.59 \%(\mathrm{p}=0.000)$ after the socialization. In conclusion, socialization has succeeded in increasing the knowledge and understanding of Inpres Rimuku Elementary School students about COVID-19 and its prevention.
\end{abstract}

Keywords: COVID-19; Education; Healthy lifestyle; Infectious disease; School; Student knowledge

\section{Introduction}

COVID-19 or Coronavirus-disease-2019 was declared a pandemic by WHO as of March 11, 2020. COVID-19 infection can be transmitted through person by person. This disease can be spread through tiny droplets from the nose or mouth when coughing or sneezing. The droplets then fall on surrounding objects. If someone else touches an object that has been contaminated with these droplets, then that person touches their eyes, nose, or mouth (triangle face), then that person can be infected with COVID-19. The primary transmission mode of this disease is through droplets released when coughing or sneezing [1]. Efforts to avoid the spread of COVID-19 have led to the adaptation of new habits, including those that are currently being implemented in Indonesia, namely the $5 \mathrm{M}$, wearing masks, maintaining a distance (1 meter), washing hands with soap, and running water, reducing mobility and staying away from crowds. There are new habits to avoid the spread of COVID-19 in life. All daily activities have changed, for example, the activities of people working in the office that turns into working from home and learning activities at school for children who become online from home [2].

\footnotetext{
* Corresponding author: Dewi Ratna Sari

Department of Anatomy, Histology and Pharmacology, Faculty of Medicine, Universitas Airlangga, Surabaya, East Java, Indonesia. 
The number of children suffering from COVID-19 is less than adults. According to the government's map of the spread of COVID-19, as of July 28, 2021, 2.9\% of the total positive confirmed cases were children aged $0-5$ years, and $9.9 \%$ of the total positive confirmed cases were children aged 6-18 years [3]. Children can be infected with COVID-19, get sick from COVID-19, and spread COVID-19 to others. Most children with COVID-19 have mild symptoms or have no symptoms at all. However, some children can become seriously ill from COVID-19 and may require hospitalization, intensive care, or a ventilator to help them breathe and, in rare cases, death [4]. The rate of child mortality in Indonesia as of July 28, 2021, at the age of $0-5$ years, was at $0.47 \%$ of all confirmed cases died, and at the age of $6-18$ years, it reached $0.54 \%$ [3].

COVID-19 can quickly spread when meeting face to face. Therefore, the Ministry of Education and Culture issued Circular Letter Number 15 of 2020 concerning Guidelines for Organizing Learning from Home in an Emergency Period for the Spread of COVID-19. The circular states that implementing Learning from Home ensures the fulfillment of students' rights to obtain educational services during the COVID-19 emergency, protect education unit residents from the adverse effects of COVID-19 and prevent the spread and transmission of COVID-19 in education units [5].

In Indonesia, all educational institutions implement the Learning from Home system, including Rimuku Inpres Elementary School, located in Mamuju Regency, West Sulawesi. Based on data from the West Sulawesi Provincial Government, as of July 23, 2021, the number of COVID-19 cases in Mamuju Regency reached 2104 cases [6]. Therefore, many COVID-19 cases in children in Indonesia and the high number of cases in Mamuju Regency have caused Rimuku Elementary School students to implement Learn-from-Home since March 2020. Therefore, a zoom meeting held the "WEAVE GOES TO SCHOOL" socialization activity for Rimuku Inpres Elementary School students to increase their knowledge about COVID-19 and its prevention.

\section{Material and methods}

This research was a descriptive-analytic research using a questionnaire containing seven questions via a google form. The research was carried out through a Zoom meeting in the "WEAVE GOES TO SCHOOL" activity, which was attended by students from grade 3-6 of Inpres Rimuku Elementary School in Mamuju Regency, by filling out a questionnaire (pretest) given via Google form before the event started to find out the students' understanding about COVID-19. Educational materials provided regarding general knowledge, symptoms, danger signs, modes of transmission, and prevention of COVID-19. The materials were given for 40 minutes in an interactive presentation. After delivering the materials, the Inpres Rimuku Elementary School students were given a questionnaire again via Google form about the materials presented before (post-test) to find out the knowledge level after the socialization. The inclusion criteria of this study were students in grades 3-6 Inpres Rimuku Elementary School, Mamuju, West Sulawesi, who did both pretest and post-test completely.

Furthermore, the data were analyzed descriptively by calculating the mean, percentage, and statistical tests using IBM SPSS version 23. The statistical test for comparative knowledge scores on the pre-test and post-test used the Wilcoxon Signed Rank test and the correlation of age with knowledge scores on the pre-test and post-test using the Spearman correlation test. The $\mathrm{p}$-value used in this study was 0.05 and significant if $\mathrm{p}<0.05$. The knowledge level criterion interval is determined by the formula from Arikunto (2010) into five categories, namely the level of knowledge is very bad (0$20)$, bad (21-40), sufficient (41-60), good (61-80), and very good. (81-100) [7].

\section{Results}

This activity was attended by 63 students of Inpres Rimuku Elementary School and only 36 students met the inclusion criteria in this study. The characteristics of the students of Inpres Rimuku Elementary School Mamuju-West Sulawesi based on class and age can be seen in Figure 1.

The educational socialization activity "WEAVE GOES TO SCHOOL" was attended by Inpres Rimuku Elementary School students in grades $3,4,5$, and 6 . Most of the socialization participants were grade 5 students, namely $69 \%$ and $50 \%$ of the total participants was ten years old.

Based on table 1 and figure 2, it appears that the number of correct answers increased on all questions. The question with the highest increase in the percentage of correct answers of $76.47 \%$ was the question "Which is a danger sign from COVID-19?" This is followed by the question "True or False if healthy children will not contract COVID-19" with 42.86\%. Then the question "How many steps are there to wash hands?" with the difference of $30.77 \%$. The three questions had the smallest percentage of correct answers during the pre-test. Therefore, it appears that the provision of material 
increased the students' knowledge, which can be seen from the increase in the percentage of correct answers during the Post-test.

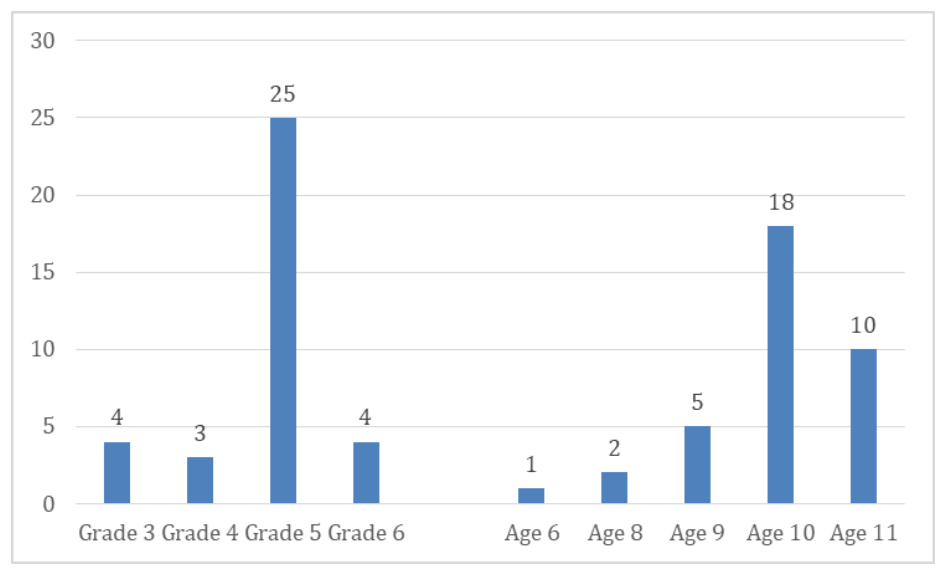

Figure 1 Distribution of students from Inpres Rimuku Elementary School Mamuju-West Sulawesi by class and age $(\mathrm{n}=$ 36)

Table 1 List of questions and the number of correct answers for students at Inpres Rimuku Elementary School, Mamuju, West Sulawesi before (pre-test) and after (post-test) socialization about COVID-19 and its prevention ( $\mathrm{n}=36)$

\begin{tabular}{|l|l|l|l|l|}
\hline \multirow{2}{*}{ No. } & \multirow{2}{*}{ Questions } & \multicolumn{2}{|c|}{ Number of Correct } & \multirow{2}{*}{ Difference } \\
\cline { 3 - 4 } & & Pre-test & Post-test & \\
\hline 1 & What is the cause of COVID-19 disease? & $32(88.89 \%)$ & $36(100 \%)$ & \multirow{2}{*}{$4(12.50 \%)$} \\
\hline 2 & What are the symptoms caused by COVID-19? & $33(91.67 \%)$ & $34(94.44 \%)$ & $1(3.03 \%)$ \\
\hline 3 & True or False if healthy children will not catch COVID-19 & $21(58.33 \%)$ & $30(83.33 \%)$ & $9(42.86 \%)$ \\
\hline 4 & Which of the following is a danger sign from COVID-19? & $17(47.22 \%)$ & $30(83.33 \%)$ & $13(76.47 \%)$ \\
\hline 5 & Which picture shows the correct wearing of a mask? & $35(97.22 \%)$ & $36(100 \%)$ & $1(2.86 \%)$ \\
\hline 6 & Which is NOT a way of transmitting Covid-19? & $35(97.22 \%)$ & $36(100 \%)$ & $1(2.86 \%)$ \\
\hline 7 & How many steps are there to wash hands? & $26(72.22 \%)$ & $34(94.44 \%)$ & $8(30.77 \%)$ \\
\hline
\end{tabular}

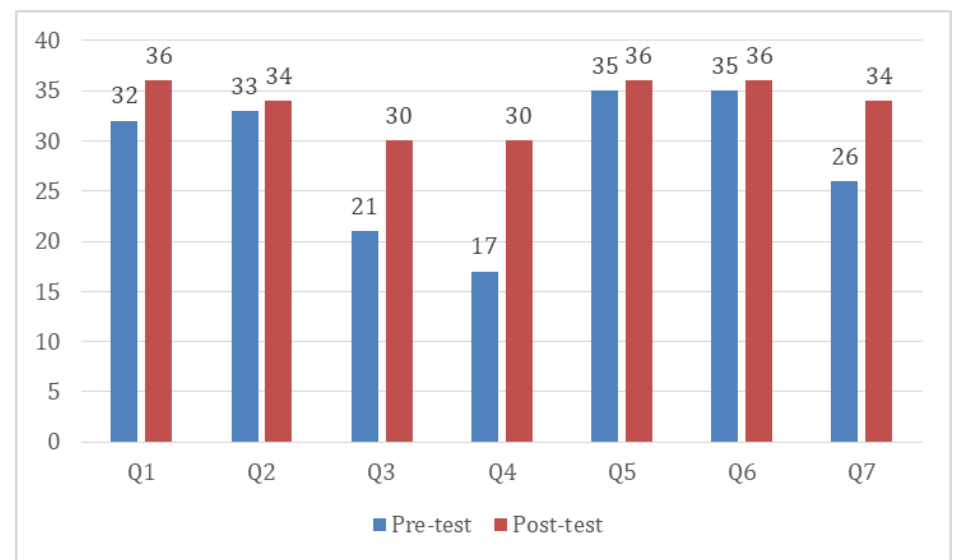

Figure 2 The number of correct answers by students of Inpres Rimuku Elementary School, Mamuju-West Sulawesi before (pre-test) and after (post-test) socialization about COVID-19 and its prevention ( $\mathrm{n}=36)$ 
Table 2 Distribution of the number of students at Inpres Rimuku Elementary School, Mamuju-West Sulawesi based on the level of knowledge before (pre-test) and after (post-test) socialization $(n=36)$

\begin{tabular}{|l|c|c|}
\hline \multirow{2}{*}{ Value Criteria } & \multicolumn{2}{|c|}{ Number of Students } \\
\cline { 2 - 3 } & Pre-test & Post-test \\
\hline Very bad & - & - \\
\hline Bad & - & - \\
\hline Enough & $9(25 \%)$ & $2(5.56 \%)$ \\
\hline Good & $7(19.44 \%)$ & $2(5.56 \%)$ \\
\hline Very good & $20(55.56 \%)$ & $32(88.89 \%)$ \\
\hline
\end{tabular}

Based on table 2, it can be seen that there were no students of Inpres Rimuku Elementary School who were included in the criteria of 'very bad' and 'bad' both before and after socialization about COVID-19 and its prevention. On the contrary, most students had a very good level of knowledge, namely $55.56 \%$ in the pre-test, and the number increased to $88.89 \%$ in the post-test.

Table 3 Results of knowledge analysis of students at Inpres elementary school Rimuku, Mamuju-West Sulawesi, before and after socialization $(n=36)$

\begin{tabular}{|l|c|c|c|c|}
\hline Score & Average \pm SD & Minimum score & Maximum score & p-value \\
\hline Pre-test Score & $78.97 \pm 17.90$ & 42.86 & 100 & \multirow{2}{*}{$0.000^{*}$} \\
\cline { 1 - 4 } Post-test Score & $93.65 \pm 12.04$ & 57.14 & 100 & \\
\hline \multicolumn{4}{|c}{ *Significant if $\mathrm{p}<0.05$, Wilcoxon Signed Rank test } \\
\hline
\end{tabular}

Table 3 showed that the average knowledge score of Inpres Rimuku elementary school students on the pretest was $78.97 \pm 17.90$ and was catagorized as good level of knowledge with 16 students scored lower than the average score. While the average value of knowledge score of Inpres Rimuku Elementary School students on the post-test was $93.65 \pm$ 12.04 , which was categorized as very good level of knowledge with $72.22 \%$ students scored higher than the average and reached the perfect score. Statistical test results showed a significant difference between students' level of knowledge before and after socialization, with an increase in knowledge of $18.59 \%(p=0.000)$. Out of 36 students, 20 students experienced an increase in knowledge score while 2 students had a decrease and 14 others got the same score after the socialization. It can be concluded that the socialization effectively increased the knowledge of Inpres Rimuku elementary school students by $55.56 \%$.

Table 4 The results of the correlation analysis of age with knowledge values during pre-test and post-test using Spearman's correlation test

\begin{tabular}{|l|c|}
\hline Variable & p-value \\
\hline Age - pre-test scores & 0.218 \\
\hline Age - post-test scores & 0.313 \\
\hline
\end{tabular}

Table 4 showed the correlation test results between age and elementary school students' knowledge during the pretest and post-test. The statistical test results of the correlation of age with the pre-test and post-test scores showed no significant correlation between age and the scores in the pre-test $(p=0.218)$ and post-test $(p=0.313)$.

\section{Discussion}

Overall, the pre-test mean value indicates a good knowledge about COVID-19 and its prevention in Rimuku Elementary School students, Mamuju Regency. These results were similar to research conducted in Sleman and Rokan Hulu, which 
showed the level of knowledge of COVID-19 and suitable prevention methods in elementary school-age children [8,9]. Elementary school-age children are part of the general population and studies conducted in Asian countries have reported high levels of knowledge about COVID-19 in the general population [10]. Research conducted by Prasetyawati (2021) reported that social media is the most effective way and place to provide information and knowledge about COVID-19 with a high level of trust. In Indonesia, social media behavior is consistent in all age groups, including children [11]. In our study, we showed a diagram and video of washing hands and wearing masked followed by a guided demonstration with all of the participants practicing each step. We also asked a few students to demonstrate what they had learned and giving feedback along the way. Some of the activities carried out can attract more students' attention because students become more engaged in learning activities and not only listen to explanations from the teacher, but other activities such as observing, doing, demonstrating and others so that students' attention to the material can be increased [12].

The percentage of students with correct answers exceeded $85 \%$ on questions regarding the causes of COVID-19 (number 1), how to spread COVID-19 (number 6), symptoms of COVID-19 (number 2), and the use of masks to prevent COVID-19 (number 2). 5) A high score on the pre-test indicates that the education program on COVID-19 on social media, television, and other government health programs were quite successful in building participants' knowledge. These results align with research conducted in Bandung, which showed a high level of knowledge about the causes and symptoms of COVID-19 among students [13].

Unfortunately, knowledge about the danger signs of COVID-19 (number 4), susceptibility or anyone who can get sick with COVID-19 (number 3), and how to wash hands properly (number 7) were still poorly understood as seen from the percentage of students with correct answers. On the pre-test, these questions scores were still less than $75 \%$. This finding is in line with research conducted on elementary school children in Ethiopia, which found that only $62.7 \%$ of students understood how to wash their hands properly [14]. These three questions percentage then increased the highest in the post-test after the material was given.

The significant difference in the mean pre-test and post-test scores illustrates the correlation between socialization about COVID-19 and its prevention at the "WEAVE GOES TO SCHOOL" event in increasing the knowledge of Rimuku Elementary School students. The same results were also reported from some research in the service activities that found a significant increase in children's knowledge about COVID-19 after providing material about COVID-19 [15,16]. This result showed the importance of education about COVID-19 and its prevention to increase school-age children's understanding. Furthermore, increased knowledge is expected to trigger changes in attitudes and behavior towards COVID-19 and its prevention. Previous research in China reported a relationship between the level of knowledge and attitudes and behavior regarding COVID-19 and its prevention [17].

The analysis results showed there was no relationship between age and knowledge, both pre-test and post-test. This analysis result was similar to previous research conducted in Tampak Siring, Gianyar that there is no relationship between the respondent's age and the level of knowledge about health [18]. In addition, research with the same result showed that the age difference does not affect a person's level of knowledge [19].

The age composition in the sample can also be the cause of relationship between of age on children's knowledge insignificant. Children with age 10 were about $50 \%$ of the total sample, so the sample tends to be homogeneous. Several studies were conducted regarding the composition of children's ages that are homogeneous and heterogeneous. Research conducted by Gray and Feldman showed that when children of different ages are combined in one class, younger children tend to benefit more because they can try activities that they cannot do alone or with friends of the same age. In addition, children tend to be more active and interactive, especially when playing games in heterogeneous classes [20].

\section{Conclusion}

The socialization was able to increase the knowledge and understanding of Inpres Rimuku Elementary School students regarding COVID-19 and its prevention. Socialization about COVID-19 and its prevention can be done in elementary school-aged children and at other higher education levels to increase children's knowledge about COVID-19 and its prevention and help reduce the number of COVID-19 spreads in Indonesia. 


\section{Compliance with ethical standards}

\section{Acknowledgments}

Thank you to Faculty of Medicine, Universitas Airlangga for facilitating the COVID-19 Module Community Service Program. Thanks are also conveyed to our supervisors during the COVID-19 Module and also a teacher from Inpres Rimuku Elementary School who has become an intermediary to us for carry out outreach activities to students of Inpres Rimuku Elementary School and to those who have helped in implementing the COVID-19 Module.

\section{Disclosure of conflict of interest}

The authors have no conflicts of interest to declare.

\section{Statement of informed consent}

Informed consent was obtained from all individual participants included in the study.

\section{References}

[1] Kementerian Kesehatan Republik Indonesia. Pertanyaan dan Jawaban Terkait COVID-19 [Internet]. Kementerian Kesehatan Republik Indonesia. 2020.

[2] Mungkasa O. Bekerja dari Rumah ( Working From Home / WFH ): Menuju Tatanan Baru Era Pandemi COVID 19 Bekerja dari Rumah. 2020; IV(2): 126-50.

[3] Satuan Tugas Penanganan COVID-19. Peta sebaran COVID-19 [Internet]. Satuan Tugas Penanganan COVID-19. 2021.

[4] Centers for Disease Control and Prevention. COVID-19 in Children and Teens [Internet]. Centers for Disease Control and Prevention. 21.

[5] Kementerian Pendidikan dan Kebudayaan. Kemendikbud Terbitkan Pedoman Penyelenggaraan Belajar dari Rumah [Internet]. Kementerian Pendidikan dan Kebudayaan. 2020.

[6] Pantau COVID-19 Sulawesi Barat. Pantauan COVID-19 Prov Sulbar [Internet]. Pantau COVID-19 Sulawesi Barat. 2021.

[7] Arikunto S. Prosedur Penelitian Suatu Pendekatan Praktik. Ed. Rev. VI, Cet. 14. Jakarta: Rineka Cipta. 2011.

[8] Azzahra IAN. Pengetahuan Terhadap Corona Virus Disease 2019 (Covid-19) Peserta Didik Kelas Atas Sd Negeri Karangnongko 1 Kecamatan Kalasan Kabupaten Sleman [Skripsi]. Yogyakarta, Universitas Negeri Yogyakarta. 2021.

[9] Wulandari S. Gambaran Pengetahuan Tindakan Preventif Penularan Covid19 Pada Anak Sd Negeri 001 Kepenuhan Hulu Kabupaten Rokan Hulu. Matern NEONATAL. 2020; 3(02): 84-92.

[10] Azlan AA, Hamzah MR, Jen T, Id S, Hadi S, Id A. Public knowledge, attitudes and practices towards COVID-19: A cross-sectional study in. 2020; 1-15.

[11] Triastuti E, Dimas, A, Akmal, N. Kajian Dampak Penggunaan Media Sosial Bagi Anak dan Remaja. Cetakan Pertama. Universitas Indonesia. 2007.

[12] Nurrita T. Pengembangan Media Pembelajaran Untuk Meningkatkan Hasil Belajar Siswa. Misykat. 2018; 03: 17187.

[13] David J, Triditra M, Sitorus T. Knowledge , Attitude , and Practices towards the COVID-19 Pandemic among Undergraduate Students. Althea Medica J. June 2021; 8: 70-6.

[14] Eshetu D, Kifle T, Hirigo AT. Knowledge, Attitudes, and Practices of Hand Washing among Aderash Primary Schoolchildren. J Multidiscip Healthc. 2020; 759-68.

[15] Erlin F, Putra ID, Hendra D. PENINGKATAN PENGETAHUAN SISWA DALAM PENCEGAHAN PENULARAN COVID19. $2020 ; 4(4): 7-9$.

[16] Zukmadini AY, Karyadi B, Kasrina. Edukasi Perilaku Hidup Bersih dan Sehat (PHBS) dalam Pencegahan COVID19 Kepada Anak-Anak di Panti Asuhan. J Pengabdi Magister Pendidik IPA. 2020; (3)(1): 68-76. 
[17] Zhang M, Zhou M, Tang F, Wang Y, Nie H, Zhang L, et al. Knowledge, attitude, and practice regarding COVID-19 among healthcare workers in Henan, China. J Hosp Infect. 2020; 105(1): $183 \mathrm{e} 187$.

[18] Dharmawati, IGAA, Wirata IN. Hubungan Tingkat Pendidikan, Umur, dan Masa Kerja dengan Tingkat Pengetahuan Kesehatan Gigi dan Mulut pada Guru Penjaskes SD di Kecamatan Tampak Siring Gianyar. Jurnal Kesehatan Gigi. 2016; 4(1): 1-5.

[19] Nengah I, Nengah IBS, Ahmad FA, Chrysella R, S DA, Farah K, et al. Hubungan Usia dengan Pengetahuan dan Perilaku Penggunaan Suplemen pada Mahasiswa Institut Teknologi Sepuluh Nopember. J Farm Komunitas. 2019; 7(1): 1-7.

[20] Gray P, Feldman J. Playing in the Zone of Proximal Development: Qualities of Self-Directed Age Mixing between Adolescents and Young Children at a Democratic School. American Journal of Education. 2004; 110(2): 108-146. 